\title{
THE ROLE OF THE ORGANIZATION COMMITMENT IN MEDIATING EFFECT AND CULTURAL ORGANIZATION LEADERSHIP STYLE ON THE PERFORMANCE OF EMPLOYEES ON RELIGIOUS MINISTRY OFFICE CITY DENPASAR
}

\author{
I Made Dwita Putra \\ Post Graduate Management student at the University Mahasaraswati Denpasar, Bali, Indonesia \\ Nengah Sudja \\ Associate Professor in Management Postgraduate Mahasaraswati University Denpasar Bali, Indonesia \\ Anak Agung Putu Agung \\ Professor in Management Postgraduate Mahasaraswati University Denpasar Bali, Indonesia \\ DOI: $10.31364 / \mathrm{SCIRJ} / \mathrm{v} 8.18 .2020 . P 0820 \mathrm{XX}$ \\ http://dx.doi.org/10.31364/SCIRJ/v8.i8.2020.P0820XX
}

\begin{abstract}
This study aims to explain the effect of leadership style, organizational culture and organizational commitment to employee performance and knowing whether organizational commitment is a mediating variable. This study used a sample of 75 employees of the Office of the Ministry of Religion in Denpasar City with a sampling technique that is saturated sampling. The data obtained were analyzed by descriptive analysis and PLS. The results found that leadership style did not directly influence employee performance. Budaya organization and organizational commitment and significant positive effect on employee performance. Leadership style and organizational culture have a positive and significant effect on organizational commitment. Furthermore, organizational commitment is able to mediate the influence of leadership style on employee performance, but is not able to mediate the influence of organizational culture on employee performance.
\end{abstract}

Keywords: leadership style, organizational culture, organizational commitment, employee performance

\section{INTRODUCTION}

Performance is the realization of tasks assigned to employees based on personal qualifications within reasonable limits (Kalkavan and Katrinli, 2014). Viewed from the perspective of the organization, performance refers to the goods or services provided as a result of the realization of the tasks given to employees in accordance with organizational goals. Performance is a very important part in determining the success of an organization. Poor and non-optimal performance reflects an organization's inability to manage its employees well. This can be caused by the leadership style that is not appropriate, employees do not understand the organizational culture that is applied and lack of commitment to the organization.

In an effort to improve employee performance, especially at the Office of the Ministry of Religion in Denpasar, it is quite difficult. This is because, this problem not only concerns the ability to carry out a job, but also concerns how a leader moves his subordinates, the loyalty of an employee, and the application of his organizational culture. Several studies have revealed a number of variables that can affect employee performance, but in this study the observed variables are Leadership Style, Organizational Culture, and Organizational Commitment.

Leadership has an important role in an organization, especially in enhancing the role of employees themselves and coordinating to work together to overcome problems that exist in an organization (Prabowo, 2018). Leadership Style is a pattern of behavior and strategy that is liked and often applied by a leader in order to achieve organizational goals (Rivai, 2009). Mulyasa (2003) explains the occurrence of various changes in society and the multidimensional crisis that has long hit Indonesia, making it difficult to find the ideal leader who has a high commitment to his duties and responsibilities. Various fields of life are found by many leaders who are actually not worthy enough to carry out their leadership mandate.

The success of an organization is very dependent on the effectiveness of leadership contained in the organization concerned, a leader must be able to create a harmonious working relationship, both between fellow employees, as well as between superiors and subordinates. Here leaders need to pay attention to the performance of their employees so that later these employees will have good organizational commitment and ultimately their performance will increase (Gatling, et al, 2016) 
Organizational culture is a value or understanding or agreement taken in an organization, in order to achieve its purpose. However, in practice there are often differences of opinion between one another. The prevailing culture is applied varies by each employee who is part of the organization. That causes the performance of each employee to be different. The implementation of this organizational culture, especially at the Office of the Ministry of Religion in Denpasar, greatly affects employee commitment and performance. The impact of implementing organizational culture on organizational commitment can be seen from the large number of employees who arrive late on work days, employees are often absent during working hours, and there are still employees who are lazy. This explains that the commitment of Denpasar City Ministry of Religion Office employees has not been maximized (Nasution, 2018); (Lolowang, 2019)

In general, commitment has become an issue related to the performance of an employee. A strong commitment to the organization will be able to reduce the likelihood of someone leaving the organization. The stronger the culture in an organization will also certainly strengthen the commitment of employees towards the organization where they work. As found by Rantesalu (2017) states that organizational culture has a positive and significant influence on organizational commitment. The same thing was found by Azizollah (2016) and Sholahudin (2018) who in their research mentioned a significant relationship between organizational culture and organizational commitment.

Appropriate leadership style and harmony of goals achieved between employees and the organization through culture will build an organizational commitment within the employee. Organizational commitment has a relationship with employee performance, with the commitment the employee's performance will also increase. Research conducted by Khushk, Amir Ali (2019) found that organizational commitment has a correlation with employee performance. The same thing was also found by Hafiz, (2017) and Rantesalu (2017) who stated that there was a positive and significant relationship between organizational commitment and employee performance.

The role of organizational commitment can also mediate the relationship between leadership style and organizational culture with employee performance. As in research conducted by Almutairi (2016) states that organizational commitment mediates the relationship between transformational leadership and employee performance. Another thing, as in a study conducted by Nikpour, Amin (2017) states that organizational commitment mediates the relationship between organizational culture and employee performance.

Based on the aforementioned background description, a study was conducted with the aim of analyzing the Role of Organizational Commitment in Mediating the Effect of Leadership Style and Organizational Culture on Employee Performance at the Office of the Ministry of Religion in Denpasar.

\section{LITERATURE REVIEW}

\section{Leadership Style and Employee Performance}

Iqbal, et al (2015) found that leadership style has a positive influence on employee performance. In addition, research conducted by Candra (2016) also explains the same thing related to a positive relationship between leadership style and employee performance. The results of this study are also supported by research conducted by Chua, et al. (2018) and Piedade (2019) who also found a positive and significant relationship between the Leadership Style and Employee Performance.

\section{Organizational Culture and Employee Performance}

Research conducted by Nasution (2018) found that organizational culture had a positive and significant effect on employee performance. Kawiana, I. Gede Putu, et al (2018) stated that the influence of organizational culture variables on significant employee performance interest and Lolowang (2019) also found a significant relationship between organizational culture and employee performance.

\section{Leadership Style and Organizational Commitment}

Several studies have found a positive relationship between leadership style and organizational commitment. Gatling, et al (2016) found that leadership style has a positive effect on organizational commitment in the hospitality industry. Furthermore, research conducted by Din, Maaz Ud, et al (2019) also found that transformational leadership styles affect organizational commitment positively and significantly. The same thing was expressed by Han, Seung Hyun, et al (2016) and Khan, Rao Shahzaib, et al (2017) who stated a positive correlation between transformational leadership and organizational commitment.

\section{Organizational Culture and Organizational Commitment}

Several studies have found a positive relationship between organizational culture and organizational commitment. Rantesalu (2017) in his research stated that organizational culture has a positive and significant influence on organizational commitment. The same thing was found by Azizollah (2016) and Sholahudin (2018) who in their research mentioned a significant relationship between organizational culture and organizational commitment.

\section{Effect of Organizational Commitment on Employee Performance Organizational}

commitment has a relationship with employee performance, with the commitment the employee's performance will also increase. Research conducted by Khushk, Amir Ali (2019) in his research found that organizational commitment has a correlation with employee performance. The same thing was also found by Hafiz, A. Z (2017) and Rantesalu (2017) who stated that there was a positive and significant relationship between organizational commitment and employee performance.

\section{RESEARCH METHODS}

In this study data were collected in an manner $e x$ post facto, in other words researchers relied on respondents' 
perceptions to explain their experiences and then were analyzed according to causal designs.

The location of the study was conducted at the Office of the Ministry of Religion in Denpasar, with 75 employees as civil servants (PNS). The object of research is all civil servants in the Office of the Ministry of Religion in Denpasar City, the time of the research conducted is 2020. The scope of this study is limited to knowing the role of organizational commitment in mediating the influence of leadership style and organizational culture on employee performance at the Office of the Ministry of Religion in the City Denpasar.

Data collection techniques in this study used a questionnaire tool, where respondents chose one of the answers provided, with alternative answers consisting of intervals of 1 to 5 . The results and interpretation of the discussion will be concluded and further research suggestions will be given. There are three types of variables in this study namely: exogenous variables (leadership style and organizational culture), mediating variables (Organizational commitment), and endogenous variables (employee performance).

Organizational commitment testing in mediating the influence of leadership style and organizational culture on employee performance is done using PLS analysis. The test results are then discussed and concluded. The research conclusions are then confirmed by the research problem and the hypothesis formulated.

\section{RESULTS AND DISCUSSION}

\section{Results of Data Analysis \\ Results Hypothesis}

\section{1) Testing Direct Effect Testing}

research uses an approach analysis Partial Least Square $(P L S)$ to test and analyze the research hypotheses previously stated. The results of empirical research model analysis using analytical tools Partial Least Square (PLS) can be seen in Figure 1 below:

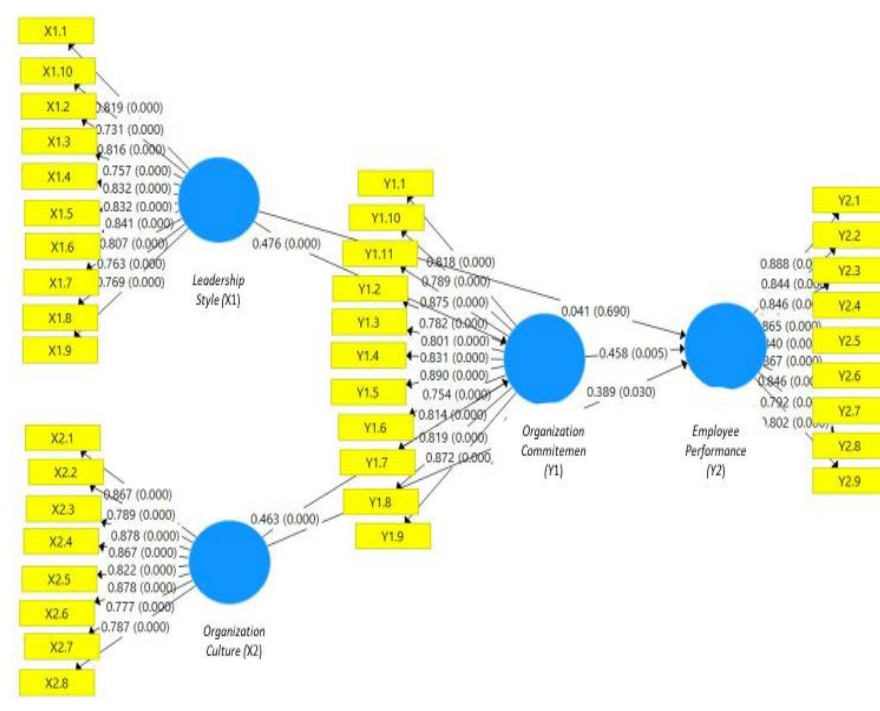

This hypothesis testing results of the analysis showed the effect of leadership style on employee performance produce a correlation coefficient of 0.041 . The value of $t$-Statistics obtained is 0.399 ( $<\mathrm{t}$ critical 1.96), and the value $P$ of 0.690 ( $>0.05)$, it can be interpreted that the leadership style has no direct effect on employee performance. Thus hypothesis 1 (H1) which states that leadership style has a positive and significant effect on employee performance is not accepted.

The analysis shows that hypothesis testing on the influence of organizational culture on employee performance produces a correlation coefficient of 0.389 . The value of $t$ statistic is 2,181 ( $>\mathrm{t}$ critical 1.96 ), and the value is $P 0.030$ $(<0.05)$, so the influence of organizational culture on employee performance is significant. Thus, hypothesis $2\left(\mathrm{H}_{2}\right)$ which states that organizational culture has a positive and significant effect on employee performance is accepted.

The results of the analysis in table 5.11 show hypothesis testing on the influence of leadership style on organizational commitment resulting in a correlation coefficient of 0.476 . The value of $t$ statistic is 3.537 ( $>$ critical $t$ 1.96), and the $P$ value is $0.000(<0.05)$, so the influence of leadership style on organizational commitment is positive and significant. Thus hypothesis 3 (H3) which states that leadership style has a positive and significant effect on organizational commitment is accepted.

The analysis shows that hypothesis testing on the influence of organizational culture on organizational commitment results in a correlation coefficient of 0.463 . The value of $t$ Statistics is 3,618 (>t critical 1,96) and the $\mathrm{P}$ value is $0,000(<0,05)$, so the influence of organizational culture on organizational commitment is significant. Thus, hypothesis 4 $\left(\mathrm{H}_{4}\right)$ which states that organizational culture has a positive and significant effect on organizational commitment is accepted.

The analysis shows that hypothesis testing on the effect of organizational commitment on employee performance produces a correlation coefficient of 0.458 . The value of $t$ Statistics is obtained for 2.846 (> t critical 1.96) and the $\mathrm{P}$ value of $0.005(<0.05)$, then the effect of organizational commitment on employee performance is significant. Thus, hypothesis $5\left(\mathrm{H}_{5}\right)$ which states that organizational commitment has a positive and significant effect on employee performance is accepted.

\section{2) Testing Results The Role of Mediation Organizational Commitment On the Influence of Leadership Style and Culture Organization Against Employee Performance}

Test mediating role of organizational commitment on the influence of leadership style and organizational culture on employee performance by examining the coefficient of direct influence of variables of leadership style and organizational culture to variable employee performance on a model involving variable organizational commitment. The results of the mediation test have shown the following:

a. The influence of the leadership style variable on the organizational commitment variable (Effect B) is significant, as indicated by the $\mathrm{P}$ value of 0,000 . The influence of leadership style variables on employee performance (Effect $\mathrm{A}$ ) is not significant, with a $\mathrm{P}$ Value

The results of Output PLS 
of 0.690. Furthermore, the influence of leadership style variables on employee performance through organizational commitment variable (Effect C) is significant, with a P Value of 0.013 . Then it can be said mediation occurs in full.

b. The influence of organizational culture variables on organizational commitment variable (Effect B) is significant, with a P Value of 0,000 . The influence of organizational culture variables on employee performance (Effect $\mathrm{A}$ ) is significant, with a $\mathrm{P}$ Value of 0.030 . However, the influence of organizational culture variables on employee performance through organizational commitment variable (Effect C) is not significant, which is indicated by the $\mathrm{P}$ Value of 0.077 (greater than 0.05). In addition, the value of the effect coefficient $\mathrm{D}$ with a value of 0.212 is smaller than the value of the effect coefficient $A$, which is 0.389 , so it can be said that there is no mediation.

\section{Discussion}

The Effect of Leadership Style on Employee Performance The

results of the analysis show that there is no direct influence of leadership style on employee performance. This means that the leadership style applied at the Office of the Ministry of Religion in Denpasar, whether directive leadership, supportive leadership, participatory leadership, or good or bad orientation orientation leadership will not directly affect the performance of employees themselves. This is because there are other variables that bridge these leadership style variables in order to have an effect on employee performance at the Office of the Ministry of Religion in Denpasar.

The results of the data processing of the research instrument / questionnaire on the leadership style variables at the Office of the Ministry of Religion in Denpasar showed a very strong average value. The directive leadership style which states that superiors always provide direct direction in work, superiors always give clear instructions to employees related to work to be done, and superiors always be assertive in making decisions, showing very strong judgment. Supportive leadership which states that superiors always make good relations in terms of communication with employees, superiors always pay attention to conflicts that occur in employees, and superiors always provide solutions if employees ask about problems related to work, showing a strong value. Furthermore related to participatory leadership which states that superiors receive and pay attention to input and information from employees, superiors are always together with employees in making a decision, showing strong judgment. And finally the leadership orientation achievement which states that superiors give challenging jobs to employees and superiors always motivate employees to work optimally shows a very strong value.

Things like this can be interpreted, from the perspective of the employees themselves, the leader figure in the Office of the Ministry of Religion of Denpasar City has a strong spirit, decisiveness, and nurturing employees in carrying out daily tasks in the agency. However, in spite of this the outline of the leadership role does not have a direct influence on the performance of the employees themselves. These results are consistent with several findings from previous studies, such as Chua, et al (2018), Prabowo, et al (2018), Lolowang,et al (2019) who also found that leadership style had no effect on employee performance.

\section{The Influence of Organizational Culture on Employee Performance}

The analysis shows that organizational culture has a positive and significant effect on employee performance. This has the meaning that the stronger the implementation of the organizational culture of the Office of the Ministry of Religion in Denpasar by employees, the higher the employee's performance. This explains that the organizational culture of the Office of the Ministry of Religion of Denpasar City is reflected through the cultural dimension of kinship such as always being good among colleagues. Employees are able to maintain feelings of each other by always being kind to maintain family relationships as upheld by organizational culture. Overall employees are able to maintain feelings when there are differences in interests that occur.

The organizational culture of the Denpasar City Ministry of Religion Office was also later reflected through the cultural dimension of tasks such as, always trying to improve performance. The employees continue to strive to always improve performance so that it in line with the organizational culture of the task. This task culture is very important to determine the success or failure of an organization, because it is related to the performance that will later be seen and assessed by the community. In addition, the organizational culture of the Denpasar City Ministry of Religion Office was also later reflected through a bureaucratic cultural dimension, such as always following the work code of ethics and obeying applicable regulations, able to improve employee performance. Every organization definitely needs a bureaucracy in it. The bureaucracy in question functions to regulate the structure of the task flow and authority in each organizational structure, not just to complicate work processes both vertically and horizontally. If arranged and managed properly, the bureaucracy will have a positive impact on the Office of the Ministry of Religion in Denpasar.

All dimensions of organizational culture, namely family culture, tasks and bureaucracy, will certainly have a positive impact on employee performance which can be reflected through the dimensions of work time, such as being able to complete work on time. A job if done well, but not on time will certainly harm the organization, both in terms of time and cost. It is hoped that through the application of organizational culture, the employees of the Office of the Ministry of Religion in Denpasar will be able to work more effectively, so that the time needed to complete work can be shortened and the results optimal. In addition, performance will also be reflected through the dimensions of cooperation, where employees become able to establish good cooperation among fellow colleagues. This is a positive impact of the implementation of organizational culture, especially family culture, because the employees are able to establish good cooperation because they always behave well among colleagues. Thus, through good cooperation will have a good impact on employee performance.

This finding can be interpreted that if employees are able to apply organizational culture in the Office of the Ministry of Religion in Denpasar well, it will be able to make a significant contribution to improve their performance. This 
result is in accordance with several previous studies, namely Nasution, et al (2018), Lolowang,et al (2019), Rantesalu, et al (2017), Sholahudin, et al (2019), who also found that organizational culture had a significant effect on employee performance.

\section{Effect of Leadership Style on Organizational Commitment The}

results of the analysis show that leadership style has a positive and significant effect on organizational commitment. This means that the stronger the leadership style at the Office of the Ministry of Religion in Denpasar, the higher the commitment of employees towards the organization. This shows that the leadership style at the Office of the Ministry of Religion in Denpasar is reflected through the directive leadership dimension such as superiors always giving direct direction in work, superiors always give clear instructions to employees related to work to be completed, and superiors always be firm in making decisions will affect an employee's commitment to his organization. Direction from a leader who is firm and clear will be quickly understood by an employee.

The leadership style of the Office of the Ministry of Religion in Denpasar through supportive leadership dimensions such as superiors always have good relations in terms of communication with employees and superiors always provide solutions if employees ask about work-related problems make employees feel cared about in carrying out their work. Furthermore, through participatory dimensions such as superiors receive and pay attention to input and information from employees make employees feel they get an appreciation for the work carried out. And the last dimension of leadership orientation achievement like superiors always motivate employees to work optimally will make employees have enthusiasm in carrying out their work.

All of the dimensions of leadership style that have been mentioned, will affect the commitment to the organization. This commitment is reflected through the dimensions of affective commitment, namely employees become highly committed to be willing to be involved in the problems facing the organization, feel the organization becomes meaningful to themselves, and feel part of the organization. The employees showed their willingness to be involved in various things facing the organization. This is because they feel that they have become part of the organization. Organizations become meaningful in themselves and certainly reflect Organizational commitment.

This finding can be interpreted that if the leadership style at the Office of the Ministry of Religion in Denpasar is well managed, it will be able to make a significant contribution to increase the commitment of their Organizations. This result is in accordance with some previous studies namely Gatling, et al (2016), Din, Maaz Ud, et al (2019), Han, Seung Hyun, et al (2016), Khan, Rao Shahzaib, et al (2017), Mesu , et al (2015), Harwiki (2016), who also found that leadership style had a significant effect on organizational commitment.

\section{The Effect of Organizational Culture on Organizational Commitment The}

results of the analysis show that organizational culture has a positive and significant effect on organizational commitment. This has the meaning that the stronger the organizational culture of the Office of the Ministry of Religion in Denpasar, the higher their commitment to the organization. This explains that the organizational culture of the Office of the Ministry of Religion of Denpasar City is reflected through the cultural dimension of kinship such as always being good among colleagues. This shows that employees are able to maintain the feelings of each other by always being kind to maintain family relationships as upheld by organizational culture. They can protect their feelings if there are differences in interests that occur. It is also important to maintain employee commitment to the organization, because commitment will be stronger if they are able to create high solidarity like a family, so comfortable when doing work.

The organizational culture of the Office of the Ministry of Religion of Denpasar City through the cultural dimension of tasks such as always trying to improve performance will also certainly increase the commitment of employees. This is because the culture of duty can increase the morale of employees who have an impact on increasing their commitment to the organization. Organizational culture through bureaucratic dimensions of culture, such as always following the work code of ethics and obeying applicable regulations, is able to increase employee commitment to the organization. The existence of a bureaucratic culture is expected to be able to regulate the structure of the task flow and authority in each organizational structure, so that it is in accordance with procedures. If arranged and managed properly, the bureaucracy will have a positive impact on the Office of the Ministry of Religion in Denpasar.

All of the dimensions of organizational culture that have been mentioned, will affect the commitment to the organization. This commitment is reflected through the dimensions of affective commitment, namely employees become highly committed to be willing to be involved in the problems facing the organization, feel the organization becomes meaningful to themselves, and feel part of the organization. The employees showed their willingness to be involved in various things facing the organization. This is because they feel that they have become part of the organization. Organizations become meaningful in themselves and certainly reflect Organizational commitment.

This finding can be interpreted that if employees are able to apply organizational culture in the Office of the Ministry of Religion in Denpasar well, it will be able to make a significant contribution to increase the commitment of their organizations. This result is in accordance with some previous studies namely Kawiana, et al (2018), Rantesalu, et al (2017), Azizollah, et al (2016), Sholahudin, et al (2019), which also found that organizational culture had a significant effect on organizational commitment.

\section{The Effect of Organizational Commitment on Employee Performance \\ The results of the analysis show that organizational} commitment has a positive and significant effect on employee performance. This means that the higher the commitment of the Denpasar City Ministry of Religion's Office staff to the organization, the higher their performance will be. This explains that the commitment of employees to the Office of the Ministry of Religion in Denpasar is reflected through the 
dimensions of affective commitment that employees become highly committed to being willing to be involved in the problems facing the organization, feel the organization is meaningful to themselves, and feel part of the organization, able to improve employee performance. The employees showed their willingness to be involved in various things facing the organization. This is because they feel that they have become part of the organization. Organizations become meaningful in themselves and certainly reflect Organizational commitment.

Based on the aforementioned affective commitments, employee performance will further be reflected through the dimensions of work time ie they become capable of completing work in a timely manner, and through the dimension of cooperation that is they are able to establish good cooperation among fellow colleagues. Judging from the dimensions of work time, such as being able to complete the job in a timely manner. A job if done well, but not on time will certainly harm the organization, both in terms of time and cost. It is hoped that through the application of organizational culture, the employees of the Office of the Ministry of Religion in Denpasar will be able to work more effectively, so that the time needed to complete work can be shortened and the results optimal. In addition, performance will also be reflected through the dimensions of cooperation, where employees become able to establish good cooperation among fellow colleagues. This is a positive impact of the implementation of organizational culture, especially family culture, because the employees are able to establish good cooperation because they always behave well among colleagues. Thus, through good cooperation will have a good impact on employee performance.

This finding can be interpreted that if employees have a high organizational commitment to the Office of the Ministry of Religion in Denpasar, they will be able to make a significant contribution to improve their performance. This result is in accordance with several previous studies namely Kawiana, I. Gede Putu, et al (2018), Rantesalu, et al (2017), Giri, et al (2016), Khushk, Amir Ali (2019), and Hafiz, AZ (AZ 2017) which also found that organizational commitment significantly influenced employee performance.

\section{The Role of Organizational Commitment in Mediating the Effect of Leadership Style on Employee Performance}

Hypothesis testing results prove that leadership style has no effect on employee performance, leadership style has a significant effect on organizational commitment, and organizational commitment has a significant effect on employee performance, it can be explained that organizational commitment as full mediation between the influence of leadership style on employee performance. This shows that the leadership style does not directly affect employee performance. Organizational commitment variable becomes an important factor in determining the influence of leadership style on employee performance in an organization. It can be explained that leadership style is not able to influence employee performance without organizational commitment. With a high level of commitment to the organization, the results of the study showed a significant impact in order to improve the performance of the Office of the Ministry of Religion's Office of Denpasar.
These results support the results of Almutairi's research, Dhaifallah Obaid (2016) who found organizational commitment as mediating the influence of leadership style on employee performance. This finding provides an additional contribution as empirical evidence regarding organizational commitment that can be a mediator between leadership style and employee performance.

\section{The Role of Organizational Commitment in Mediating the Effect of Organizational Culture on Employee Performance}

Hypothesis testing results prove that organizational culture has a significant effect on employee performance, organizational culture has a significant effect on organizational commitment, but organizational culture does not affect employee performance through organizational commitment, it can be explained that organizational commitment does not mediate the influence of organizational culture on employee performance. This shows that without going through organizational commitment, organizational culture already has a positive and significant direct influence on the performance of the Ministry of Religion's Office staff in Denpasar.

This finding provides an additional contribution as empirical evidence of organizational commitment that does not mediate the relationship between organizational culture and employee performance.

\section{CONCLUSIONS AND SUGGESTIONS}

\section{Conclusions}

Based on the research problem, objectives, hypotheses, and the results of the discussion in the previous chapter, it can be concluded as follows.

1. Leadership style does not affect employee performance. This means that the leadership style does not directly affect employee performance.

2. Organizational culture has a positive and significant effect on employee performance. This means that the better the application of organizational culture by employees, the better the performance of employees

3. Leadership style has a positive and significant impact on organizational commitment. This means that the better the application of leadership style, the higher the organizational commitment of employees

4. The organizational culture has a positive and significant effect on organizational commitment. This means that the better the application of organizational culture by employees, the higher the organizational commitment of employees.

5. Organizational commitment has a positive and significant effect on employee performance. This means that the higher the organizational commitment of employees, the better the performance of employees.

6. Organizational commitment is proven as a full mediation between the influence of leadership style on employee performance. This means that without organizational commitment, leadership style alone is not able to influence employee performance. However, through organizational commitment, the influence of 
leadership style on employee performance becomes positive and significant.

7. Organizational commitment does not mediate the influence of organizational culture on employee performance. This means that with organizational commitment, organizational culture does not affect employee performance. However, directly the organizational culture has a positive and significant effect on employee performance.

\section{Suggestions}

Based on the results of research and conclusions, here are some suggestions for improving employee performance through leadership style, organizational culture and organizational commitment.

1) Based on the descriptive analysis of supportive leadership and participative leadership at the Office of the Ministry of Religion of Denpasar City tends to be lower than the value of the overall leadership style variable. In the future, relations can be further improved in terms of communication between superiors and employees, superiors always pay attention to conflicts that occur with employees, and superiors to be able to receive and pay attention to input and information from employees, which will certainly be able to create a more comfortable working atmosphere.

2) Based on the results of a descriptive analysis, Denpasar City Ministry of Religious Affairs employees are known to have a slightly lower adaptive culture. This is indicated by the inability to adjust for input from the community. In the future, all employees need to pay attention if there are criticisms and suggestions from outside the organization, it should be immediately followed up so that what is lacking from the organization in the service sector can be corrected. The leadership should also be consistent in reminding their employees to always absorb and practice the organizational culture of the Office of the Ministry of Religion in Denpasar, especially the adaptive culture.

3) Based on the results of a descriptive analysis, Denpasar City Ministry of Religion Office employees are known to have lower affective commitment and continuance commitment. Low affective commitment is shown by the feeling that the work in this organization is not specific work. Low sustained commitment is demonstrated by feeling as if life will not be disrupted if it decides to leave the organization. Suggestions for this can be by doing things that can increase employee commitment, for example by increasing harmony in the work environment, increasing their motivation, and always conveying common goals in every meeting or meeting.

4) Based on the results of descriptive analysis, Denpasar City Ministry of Religion employees are known to have a quantity of work that is not optimal. Judging from not being able to do work in accordance with the specified quantity / target. In the future direction, leaders need to take this seriously through the control of employees and the work process. If the results of the control or evaluation are found to be a source of problems from the ineffectiveness of their performance, for example because there are some employees who transfer their work to coworkers, then the leader can give a reprimand and sanction.

\section{REFERENCES}

[1] Almutairi, Dhaifallah Obaid. "The mediating effects of organizational commitment on the relationship between transformational leadership style and job performance." International Journal of Business and Management 11.1 (2016): 231.

[2] Azizollah, Arbabisarjou, Farhang Abolghasem, and Dadgar Mohammad Amin. "The relationship between organizational culture and organizational commitment in Zahedan University of Medical Sciences." Global journal of health science 8.7 (2016): 195.

[3] Chandra, Teddy. "The Influence of Leadership Styles, Work Environment and Job Satisfaction of Employee Performance--Studies in the School of SMPN 10 Surabaya." International Education Studies 9.1 (2016): 131-140.

[4] Chang, SC and Lee, MS 2007. A study on relationship among leadership, organizational culture, the operation of learning organization and employees' job satisfaction. The Learning Organization, 14(2), pp: 155 - 185.

[5] Chua, Joyce, Abdul Basit, and Zubair Hassan. "Leadership styles and its impact on employee performance." International Journal of Accounting \& Business Management 6.1 (2018): 80-94.

[6] Colquitt, LW Organizational Behavior Improving Performace and Commitment in The Workplace. New York: Mc Graw Hill International Edition. (2009)

[7] Denison, DR and Mishra, AK 1995. Toward a theory of organizational culture and effectiveness. Organization Science, 6(2), pp: 204-23.

[8] Din, Maaz Ud, et al. "The Moderating Role of Employee Empowerment and Distributive Justice in Transformational Leadership with Its Impact on Organizational Commitment in Islamic Banks at Pakistan." Perisai: Islamic Banking and Finance Journal 3.2 (2019): 135.

[9] Edison, Emron, Anwar, Yohny dan Komariyah, Imas. 2016. Manajemen Sumber Daya Manusia. Cetakan ke-1. Bandung : Alfabeta

[10] Gatling, Anthony, Hee Jung Annette Kang, and Jungsun Sunny Kim. "The effects of authentic leadership and organizational commitment on turnover intention." Leadership \& Organization Development Journal 37.2 (2016): 181-199.

[11] Giri, Endang Eviline, et al. "The Effect of Organizational Culture and Organizational Commitment to Job Involvement, Knowledge Sharing, and Employee Performance: A Study on Regional Telecommunications Employees of PT Telkom East Nusa Tenggara Province, Indonesia." International Journal of Management and Administrative Sciences 3.4 (2016): 20-33.

[12]Hafiz, AZ "Relationship between organizational commitment and employee's performance evidence from banking sector of Lahore." Arabian Journal of Business and Management Review 7.2 (2017): 1-7. 
[13]Han, Seung Hyun, et al. "Transformational leadership and knowledge sharing: Mediating roles of employee's empowerment, commitment, and citizenship behaviors." Journal of Workplace Learning 28.3 (2016): 130-149.

[14] Handoko, Y., Setiawan, M., Surachman, and Djumahir "Organizational Culture, Job Satisfaction, Organizational Commitment, the Effect on Lecturer Performance." International Journal of Business and Management Invention, 2(12), pp: $21-30.2013$

[15] Harwiki, Wiwiek. "The impact of servant leadership on organization culture, organizational commitment, organizational citizenship behaviour (OCB) and employee performance in women cooperatives." Procedia-Social and Behavioral Sciences 219 (2016): 283-290.

[16] Herscovitch, L., and Meyer, J. 2002. Commitment to organization change: extension of three component model. Journal of Applied Psychology, 87, pp: 474-478.

[17] Iqbal, N., S. Anwar, and N. Haider. "Effect of leadership style on employee performance." Arabian Journal of Business and Management Review 5.5 (2015): 1-6.

[18] Kalkavan, S. and Katrinli, A. 2014. The Effects of Managerial Coaching Behaviors on The Employees' Perception of Job Satisfaction, Organisational Commitment, and Job Performance: Case Study on Insurance Industry in Turkey. Procedia - Social and Behavioral Sciences, 150, pp: 1137 - 1147.

[19] Kawiana, I. Gede Putu, et al. "The influence of organizational culture, employee satisfaction, personality, and organizational commitment towards employee performance." International research journal of management, IT and social sciences 5.3 (2018): 35-45.

[20] Khan, Rao Shahzaib, et al. "The mediating role of job satisfaction between transformational leadership and organizational commitment within the SMEs of Karachi." International Journal of Applied Business and Management Studies (IJABMS) Vol 2, Issue 1 (2017): 4655.

[21] Khushk, Amir Ali. "Impact of Locus of Control (LOC) and Organizational Commitment on Employee Performance-Study of Service Sector, Pakistan." International Journal of Law and Peace Works (2019).

[22] Lewin, K., Lippitt, R., \& White, RK (1939). Patterns of aggressive behavior in experimentally created "social climates." Journal of Social Psychology, 10, 271-299.

[23] Lolowang, Nansi Lidya, and Siti Aisjah. "The effect of leadership and organizational culture on employee performance that is educated by motivation (study on the implementation empowerment programs in Jayapura city)." Problems and Perspectives in Management 17.1 (2019): 268.

[24] Lumley, EJ, Coetzee, M., Tladinyane, R., and Ferreira, N. Exploring the job satisfaction and organisational commitment of employees in the information technology environment Lumley. Southern African Business Review, 15 (1) pp: 100-118.(2011)

[25] Lunenburg, C. Fred. 2011. Self-Efficacy in the Workplace: Implications for Motivation and Performance. Sam Houstan State University, International Journal Of Management, Business, and Administration.
[26] Mesu, Jos, Karin Sanders, and Maarten van Riemsdijk. "Transformational leadership and organisational commitment in manufacturing and service small to medium-sized enterprises: The moderating effects of directive and participative leadership." Personnel Review 44.6 (2015): 970-990.

[27] Meyer, PJ, and Allen, JN 1991. A-Three Component Conceptualization of Organizational Commitment. Human Resource Management Review, 1 (1), pp: 61-89.

[28] Meyer, PJ, Herscovitch, and L., Lynne. 2001. Commitment in the Workplace: Toward a General Model. Human Resource Management Review, 11 (1), pp: 299-326.

[29] Narteh, B. 2012. Internal marketing and employee commitment: Evidence from the Ghanaian banking industry. Journal of Financial Services Marketing, 17(4), pp: $284-300$.

[30] Nasution, Fauziah Nami, Emmy Mariatin, and Siti Zahreni. "The Influence of Career Development and Organizational Culture on Employee Performance." International Journal of Scientific Research and Management 6.01 (2018).

[31] Nikpour, Amin. "The impact of organizational culture on organizational performance: The mediating role of employee's organizational commitment." International Journal of Organizational Leadership 6 (2017): 65-72.

[32]Piedade, Salustiano Dos Reis, et al. "The role of motivation: the effect of transformational leadership on employee performance." International research journal of management, IT and social sciences 6.6 (2019): 253263.

[33] Prabowo, Thoni Setyo, Noermijati Noermijati, and Dodi Wirawan Irawanto. "The Influence Of Transformational Leadership And Work Motivation On Employee Performance Mediated By Job Satisfaction." Jurnal Aplikasi Manajemen 16.1 (2018): 171-178.

[34] Rantesalu, Agustina, Abdul Rahman Mus, and Zaenal Arifin. "The effect of competence, motivation and organizational culture on employee performance: the mediating role of organizational commitment." Journal of Research in Business and Management (2017)

[35] Saleh, F. 2017. Transactional Leadership Effects, Organizational Culture, Commitment and Job Satisfaction on Compensation and Employee Performance in the Area of Agricultural Quarantine, South Sulawesi. SSRN. Available at: https://ssrn.com/abstract $=2919740$

[36] Sholahudin, Ade, Adi Setiawan, and Muhamad Alwi. "The Influence of Organizational Culture on Organizational Commitment and its Implications on the Performance of City Public Service." International Symposium on Social Sciences, Education, and Humanities (ISSEH 2018). Atlantis Press, 2019.

[37] Stanley, JD, Meyer, PJ, Herscovitch, L., and Topolnytsky, L. Affective, Continuance, and Normative Commitment to the Organization: A Meta-analysis of Antecedents, Correlates, and Consequences. Journal of Vocational Behavior, 61 (1), pp: 20-52 (2002)

[38] Wallach, EJ 1983. "Individuals and organization: The Cultural Match." In: Training and Development Journal, pp: 29-36. 
[39] Wei Bo, Z., Kaur, S., and Jun, W. 2010. New development of organizational commitment: A critical review (1960 - 2009). African Journal of Business Management, 4(1), pp: 12 - 20.

[40] Yiing, LH 2008. The Association between Organizational Culture and Leadership Behaviour and Organizational Commitment, Job Satisfaction and Employee Performance - A Malaysian Perspective. Thesis. Master of Business Administration in Faculty of Business and Accountancy University of Malaya.

[41] Yousef, DA “Organizational commitment: A mediator of the relationships of leadership behavior with job satisfaction and performance in a non-western country". Journal of Managerial Psychology, 15(1), pp: 6-28.2000 